\title{
Low Intensity Laser Therapy in Disc Derangement Disorders of Temporomandibular Joint: A Review Article
}

\author{
Terapia con Láser de Baja Intensidad en Trastornos de Alteración Discal \\ de la Articulación Temporomandibular: Un Artículo de Revisión
}

Mubeen Khan*; Vijayalakshmi, K. R.* \& Nikita Gupta**

KHAN, M.; VIJAYALAKSHMI, K. R. \& GUPTA, N. Low intensity laser therapy in disc derangement disorders of temporomandibular joint : A review article. Int. J. Odontostomat., 7(2):235-239, 2013.

ABSTRACT: Temporomandibular disorders embrace a number of clinical conditions that involves the masticatory musculature, temporomandibular joint (TMJ) and associated structures. The most frequent cause of TMJ disorders are disc derangement disorders which involve progressive slipping or displacement of articular disc. Various conservative treatment strategies for disc derangement disorders includes pharmacologic therapy, psychological counselling, treatment of parafunctional habits, use of occlusal splints and acupuncture which gives short term relief only. Recently, a non traumatic introduction to dentistry can be represented by low level laser therapy or soft laser therapy. It has proved to be an effective treatment modality in management of disc derangement disorders through its analgesic and anti- inflammatory effect. Therefore, the goal of this review article is to explore the use of low level laser therapy as an emerging trend in the management of disc derangement disorders of TMJ.

KEY WORDS: low level laser, disc derangement disorders, orofacial pain.

\section{INTRODUCTION}

Disc Derangement disorders represents a disturbance in normal anatomic relationship between the intra-articular disc and condyle resulting in an interference in smooth movement of the joint (Firestein et al., 2008). Epidemiological studies have shown that globally $20-30 \%$ patients with disc derangement are symptomatic while remaining $33 \%$ are asymptomatic. Disc derangement disorders have been considered to have a broad prevalence peak between 20 and 40 years of age. Disc derangement disorders rarely have a solitary cause and numerous factors have been proposed ranging from Acute trauma followed by which there are other factors like chronic low grade microtrauma, psychological stress and malocclusion. Disc derangement disorders are characterized by a various cardinal features like typical joint pain while opening and closing of mouth, popping and clicking of joint, tenderness in masticatory muscles and notable limitation in mandibular movements. It also is commonly associated with other symptoms affecting the head and neck region such as headache, earache, tooth pain and cervical spine disorders (Usha \& Ramesh Srinivasab, 2011).

In the last 30 years, many nonsurgical therapies have been suggested for the management of Disc derangement disorders including physical therapy, pharmacologic therapy, through psychological counselling, cognitive behavioural therapy, occlusal splints and acupuncture (Venancio et al., 2005; Cetiner et al., 2006; Petrucci et al., 2011). The main objective of all these treatment modalities is to reduce the symptom intensity, thereby improving the function of masticatory system and adjacent structures. Physical therapy seems an intuitive choice for an individual who may have pain in their musculature. Although physical therapy produces short term relief of signs and symptoms, there is little evidence suggesting that it produces a long term reduction in signs and symptoms of temporomandibular disorders (Petrucci et al.). But

\footnotetext{
* Professor and Head of the Dept., Department of Oral Medicine and Radiology, Govt. Dental College and Research Institute, Bangalore.

* Associate Professor, Department of Oral Medicine and Radiology, Govt. Dental College and Research Institute, Bangalore.

*** Post Graduate Student, Dept. of Oral Medicine and Radiology, Govt. Dental College and Research Institute, Bangalore.
} 
all these treatment modalities have not given satisfactory results for disc derangement disorders. So, Low level laser therapy (LLLT) is a new treatment modality that is becoming widely known (Venancio et al.). Among the numerous treatment modalities available for disc derangement disorders low intensity laser therapy has proven capable of long lasting pain relief (Santos et al., 2010).

Low level laser therapy. The Laser is the acronym for light amplification by stimulated emission of radiation. After the first laser was developed in 1960 by Theodore maiman in los angeles (Ruby laser-694 $\mathrm{nm}$ ), there was rapid development and interest in laser research (Sun \& Tunér, 2004). Based on power laser can be classified into 3 categories: High power laser which increases tissue kinetic energy and uses output power of more than $500 \mathrm{~mW}$, Intermediate power laser which uses output power of $250-500 \mathrm{~mW}$ and low power laser which have no thermal effect on tissues and uses power of less than $250 \mathrm{~mW}$ (Khalighi et al., 2010). Low level laser therapy is also known as "soft laser therapy", laser biostimulation can be used for various purposes in dentistry such as soft tissues, hard tissues and pain reduction (Sun \& Tunér; Kahraman, 2004; Rahimi et al., 2011). Therapeutic lasers are defined as treatment using irradiation with light at low power intensities and with wavelength in the range 540$830 \mathrm{~nm}$ (Tunér, 2011). The light has unique properties in that it is coherent, monochromatic, and collimated (Khalighi et al.). Therapeutic lasers are classified as class III medical devices, and surgical lasers as class IV. Biologic effects of therapeutic lasers are laser photobiostimulation, or biostimulation. In addition to the stimulating effect, the cellular effects also include bioinhibition. Laser light is reflected, absorbed, transmitted and scattered after entering tissue. The amount of tissue between the laser probe and the target tissue and type of tissue must be considered (Sun \& Tunér).

LLLT equipment. The lasers used in various fields may have visible wavelength (red), or invisible infrared wavelength (from 650 to $1000 \mathrm{~nm}$ ). Helium -neon lasers $(632.5 \mathrm{~nm})$ were used before, but semiconductor diode types ( 635 to 650 and 803 to $980 \mathrm{~nm}$ ) like gallium - arsenide lasers (GaAs) lasers and gallium- aluminium -arsenide (GaAlAs) lasers are used now a days (Rahimi et al.). Semiconductor diode lasers are compact and have a high conversion efficiency from electrical energy to laser energy. Laser diodes have a typical lifeexpectancy of between 100,000 and 600,000 hours. Semi-conductor diode lasers are generally variants of either Aluminium:Gallium:Arsenide (AIGaAs) which emit in the near infrared spectrum (wavelength 700$940 \mathrm{~nm}$ ), or Indium:Gallium:Arsenide:Phosphorus (InGaAsP) devices which emit in the red portion of the visible spectrum range (wavelength $600-680 \mathrm{~nm}$ ). Power outputs are typically in the order of $10-500 \mathrm{~mW}$ when measured at the level of diode laser itself (Walsh, 2012). Since wavelength is the most important factor in any type of phototherapy, it is crucial to choose the effective wavelength with desirable effects in living tissue (Rahimi et al.). The gallium aluminium arsenide (GaAIAs) diode laser is known to be a high tissue penetration laser because haemoglobin and water have a low coefficient of absorption for it (Kahraman).

The beam profile from a typical diode laser is rectangular, with a high divergence on the long axis (20 degrees from the centre axis), and a low divergence on the short axis (2 degrees). This gives a highly divergent oval or 'sweep' profile. Diode lasers may have integrated optics which produces collimated and focused light beams. To obtain a more useful beam, a series of lenses or a self-focusing graded index fibre can be used in front of the device to either deliver the treatment beam itself or to direct the laser output into a small diameter flexible optical bore or a solid light guide (similar to the light tip on a curing light). Whatever the delivery system used, it is important that the components which come into direct contact with patients are able to be protected adequately with a lasertransmissive disposable barrier, can be autoclaved, or are disposable (Walsh). Combination probes of two laser wavelengths or one or more laser diodes with LEDs of various wavelengths may be made as "cluster probes". The effect of merging an incoherent LED with the laser requires further research to determine its effectiveness. Dental therapeutic lasers are usually the size of an electric toothbrush and come with an attachable intraoral probe shaped like the wand used in composite curing light units. The power of the GaAlAs laser should not be less than $100 \mathrm{~mW}$ to obtain the desired biologic effect in a reasonable time (Sun \& Tunér).

Mechanism of action. The LLLT has complex mechanisms, but it is essentially related to the absorption of particular visible red and near infrared wavelength in photoreceptors within subcellular components and particularly the electron transport (respiratory) chain within the membranes of mitochondria (Rahimi et al.; Karu, 1989).

The three main effects of laser light used in LLLT on tissue include: 
1. Analgesic

2. Biostimulating

3. Anti- inflammatory

Analgesic effect. The principle of using LLLT is to supply direct biostimulative light energy to the body cells. Cellular photoreceptors can absorb the low level laser light and pass it on to mitochondria, which promptly produce the cells fuel, adenosine triphosphate (ATP). There is evidence suggesting that LLLT may have significant neuropharmacologic effects on the synthesis, release and metabolism of a range of neurochemicals including histamine, serotonin and acetylcholine, all of which are pain mediators (Sun \& Tunér). Laser decreases cell membrane permeability for $\mathrm{Na}+$ and $\mathrm{K}+$ and cause neuronal hyperpolarization resulting in increased pain threshold. Low-power lasers increase the urinary excretion of serotonin and glucocorticoids, increasing the production of $b$ endorphin. LLLT can help removing metabolites and increase blood flow to muscles in painful condition through local vasodilatation (Khalighi et al.).

Biostimulating effects. LLLT rises cell activity and ATP production. It also causes increased release of growth factors, cytokines and accelerates replication mechanisms that result in promotion in cell repair processes and declines the oxidative phase. Laser light can also react with $b$ growth factors and many different oxygenated molecules. Cellular oxidative state alters these factors; indeed, the effects of photobiostimulation depend on the pretreatment cell state and are therefore unpredictable (Rahimi et al.).

Antiinflammatory effects. LLLT alters blood flow and induces angiogenesis. Furthermore, it increases lymph drainage and consequently inflammation decreases (Rahimi et al.).

Effect of low laser therapy in Disc derangement disorders. Diagnosis is essential before treatment is rendered. Clinical studies of LLLT used on patients with disc derangement disorders using either AIGaAs 830 $\mathrm{nm}$ diode laser in continuous wave mode or $\mathrm{He} \mathrm{Ne}$ laser $632 \mathrm{~nm}$ combined with a diode laser $904 \mathrm{~nm}$ in pulsed mode have shown clinical benefits in terms of reduction in pain and clicking. Kulekcioglu et al., (2003) investigated the effectiveness of LLLT in the treatment of TMD and compared treatment effects in myogenic and arthrogenic cases. They observed significant reduction in pain in both treatment groups, and the number of tender points, maximal mouth opening and lateral jaw motion were significantly improved in the active treatment group compared with the treatment group. Similarly, Bertolucci \& Grey (1995) reported significant improvement in articular noise, in limitation of oral opening and in the masticatory function through reduction of muscle contraction and of intra articular inflammation by LLLT.

The application of laser beams diminishes pain while simultaneously reducing muscle contraction. When a local effect is desired, laser is effective by stimulating microcirculation and local cell tropism or, when a general therapeutic effect is needed, by promoting pain relief for a variety of etiologies, including irradiation of trigger points in myofacial pain, acting on tissue repair, reduction of edema and hyperaemia (Shinozaki et al., 2010; Schawlow, 1995).

Advantages of low level laser therapy. LLLT is a aseptic, noninvasive, painless, nonpharmaceutical and reversible therapy, if used properly has no side effects. It has no postoperative discomfort (Sun \& Tunér).

Disadvantages of low level laser therapy. The major drawback so far has been the high cost compared to the conventional therapies and the fast development in the field.

Contraindications and safety measures. Laser units used for LLLT are generally classified as Class III or Class IIIb in terms of the optical hazards which they pose to staff and patients. Because a low power treatment beam can be focused by the eye to give a high power density on the retina, the optical hazard is sufficiently great that laser safety standards mandate the wearing of appropriate protective glasses by patients and clinicians during treatment. Glasses are available which provide protection against common LLLT wavelengths in both the visible and near infrared spectrum (Walsh).

There are no reports of patients being harmed by therapeutic lasers, and class III lasers are termed nonsignificant risk medical devices. The risk of eye injury is minimal but must be considered, especially for high output lasers in the invisible range. Diode laser light is generally divergent; however if the light is collimated, the risk of eye injury increases significantly. Protective goggles, specific for wavelength must be used for the patient and therapist (Sun \& Tunér).

Although there are no contraindications reported for dental therapeutic lasers, some side effects exist. Because laser light affects several rheologic factors, 
patients with coagulation disorders need special attention (Sun \& Tunér).

Among the side effects rarely observed are:

1. Temporary increase of pain in chronic pain conditions. It has been suggested that this is a sign of a transfer of the chronic condition into an acute situation.

2. Tiredness after the treatment. This is probably a result of the pain relief where the pain previously has prevented a normal relaxation pattern.

3. Redness and a feeling of warmness in the area which is irradiated a result of increased micro circulation.

\section{CONCLUSION}

Many clinical applications of laser light can be found in medicine, dentistry, surgery and many types of lasers in different wavelengths have been offered to clinicians and researchers. Lesser-known classes of lasers have first been developed to use for its phototherapeutic effects in 1960s. There are many types of phototherapy devices with different characteristics, including helium-neon $(\mathrm{HeNe})$ and GaAIAs lasers. These devices have been applied for the conditions like wound healing, dental implantology, oral ulcers, soft tissue injuries, radiation-induced mucositis, and nerve injuries (Cetiner et al.).

In the disc derangement disorders, the TMJ clinical findings are pain and dysfunction, which appears to be due to the pain or an alteration of the disc-condyle relation and can generate limited and irregular movements and joint sounds. The TMJ pain is classified as deep and somatic, of musculoskeletal type, and can be identified by the fact that there is a relation between pain and masticatory function effort and with gradual increase on digital palpation (Venancio et al.). GaAlAs lasers are applied for the management of disc derangement disorder for its analgesic and antiinflammatory effects.

Despite the lack of scientific evidence regarding its mechanism of action, some theories try to explain its therapeutic effects: greater release of betaendorphins; maintaining the nerve cell membrane potential-reducing the transmission of nerve signals and COX inhibition, reducing local pro-inflammatory substances, and these all yield analgesic and antiinflammatory effects (Santos et al.). In view of the noninvasive action of LLLT, it can be considered a useful tool in the treatment of TMD, although further studies are required to define reliable clinical parameters. The correct diagnosis and an appropriate application protocol are key factors to enable LLLT to produce positive effects (Shinozaki et al.).

KHAN, M.; VIJAYALAKSHMI, K. R. \& GUPTA, N. Terapia con láser de baja intensidad en trastornos de alteración discal de la articulación temporomandibular: un artículo de revisión. Int. J. Odontostomat., 7(2):235-239, 2013

RESUMEN: Los trastornos temporomandibulares abarcan una serie de condiciones clínicas que involucran la musculatura masticatoria, la articulación temporomandibular (ATM) y estructuras asociadas. La causa más frecuente de trastornos de la ATM es la alteración discal que implica el deslizamiento o desplazamiento progresivo del disco articular. Diversas estrategias de tratamiento conservador para los trastornos de alteración discal incluyen el tratamiento farmacológico, la terapia psicológica, el tratamiento de los hábitos parafuncionales, uso de férulas oclusales y acupuntura, que solamente dan un alivio a corto plazo. Recientemente, una introducción no traumática para la odontología puede ser representada por la terapia con láser de baja frecuencia o terapia de láser blando. Esta ha demostrado ser una modalidad de tratamiento eficaz en el manejo de los trastornos de alteración discal a través de su efecto analgésico y antiinflamatorio. El objetivo de este artículo es explorar el uso de la terapia con láser de baja frecuencia como una tendencia emergente en el tratamiento de los trastornos de alteración del disco de la ATM.

PALABRAS CLAVE: láser de baja frecuencia, trastornos de alteración discal, dolor orofacial.

\section{REFERENCES}

Bertolucci, L. E \& Grey, T. Clinical analysis of mid-laser versus placebo treatment of arthralgic TMJ degenerative joints. Cranio, 13(1):26-9, 1995.
Cetiner, S.; Kahraman, S. A. \& Yücetas, S. Evaluation of low-level laser therapy in the treatment of temporomandibular disorders. Photomed. Laser Surg., 24(5):637-41, 2006. 
Firestein, G. S.; Budd, R. C.; Harris, E. D.; Mclnnes, I. B.; Ruddy, S. \& Sergent, J. S. Kelley's textbook of rheumatology. $8^{\text {th }}$ ed. Philadelphia, Elsevier, 2008.

Kahraman, S. A. Low-level laser therapy in oral and maxillofacial surgery. Oral Maxillofac. Surg. Clin. North Am., 16(2):277-88, 2004.

Karu, T. Photobiology of low-power laser effects. Health Phys., 56(5):691-704, 1989.

Khalighi, H. R.; Anbari, F.; Beygom Taheri, J.; Bakhtiari, S.; Namazi, Z. \& Pouralibaba, F. Effect of Low-power Laser on Treatment of Orofacial Pain. J. Dent. Res. Dent. Clin. Dent. Prospects, 4(3):75-8, 2010.

Kulekcioglu, S.; Sivrioglu, K.; Ozcan, O. \& Parlak, M. Effectiveness of low-level laser therapy in temporomandibular disorder. Scand. J. Rheumatol., 32(2):114-8, 2003.

Petrucci, A.; Sgolastra, F.; Gatto, R.; Mattei, A. \& Monaco, A. Effectiveness of low-level laser therapy in temporomandibular disorders: a systematic review and meta-analysis. J. Orofac. Pain, 25(4):298-307, 2011.

Rahimi, A.; Rabier, S.; Mojadehi, S. M. \& Kosarieh, E. Application of low level lasers in temporomandibular disorders. J. Lasers Med. Sci., 2(4):165-70, 2011.

Santos, T. S.; Piva, M. R.; Ribeiro, M. H.; Antunes, A. A.; Melo, A. R. \& Silva, E. D. Lasertherapy efficacy in temporomandibular disorders: control study. Braz. J. Otorhinolaryngol., 76(3):294-9, 2010.

Schawlow, A. L. Principles of lasers. J. Clin. LaserMed. Surg., 13(3):127-30, 1995.

Shinozaki, E. B.; Santos, M. B.; Okazaki, L. K.; Marchini, L. \& Junior, A. B. Clinical assessment of the efficacy of lowlevel laser therapy on muscle pain in women with temporomandibular dysfunction, by surface electromyography. Braz. J. Oral Sci., 9(4):434-8, 2010.

Sun, G. \& Tunér, J. Low-level laser therapy in dentistry. Dent. Clin. North Am., 48(4):1061-76, 2004

Tunér, J. Laser phototherapy in dentistry. 2011. Available in: w w w. d t s t u d y c l u b.c n / . . . I 2374c99bd30c7c26014d3cc62a5b3aae.pdf

Usha, V. \& Ramesh Srinivasab, V. Temporomandibular joint internal derangement - A review. SRM Univ. J. Dent. Sci., 2(4):334-9, 2011.

Venancio, R. A.; Camparis, C. M. \& Lizarelli, R. F. Low intensity laser therapy in the treatment of temporomandibular disorders: a double-blind study. J. Oral Rehabil., 32(11):8007, 2005.
Walsh, L. J. Low level laser therapy. Brisbane, The University of Queensland, 2012. Available in:

http://dermanova.spdev.co.nz/images/custom/lllt_article.pdf

Correspondence to:

Dr. Nikita Gupta

Department of Oral Medicine and Radiology

Government Dental College and Research Institute, Bangalore (Karnataka).

Phone: 07795074123

Email: guptaniki77@gmail.com

Received: 26-01-2013

Accepted: 02-07-2013 